\title{
De invloed van het internet op de financiële functie
}

\section{Jim Emanuels en Oscar van Leeuwen}

SAMENVATTING Welke rol krijgt de financiële afdeling in het internettijdperk? Het is een vraag die veel controllers bezighoudt, zo bleek uit een enquête bij een onlangs gehouden symposium ${ }^{1}$. In dit artikel zullen wij proberen een beeld te schetsen van de verschillende aspecten van de toepassingen van internet (e-business), hoe deze doorwerken op de financieel administratieve processen en wat de veranderingen betekenen voor de rol van de controller en de toekomst van de financiële functie. Om de impact van de veranderingen goed te kunnen inschatten, is het allereerst belangrijk om te definiëren wat onder e-business wordt verstaan, alvorens we nader ingaan op de processen die er door worden geraakt.

\section{Inleiding}

E-business is het toepassen van internetstandaarden bij het ondersteunen, ontwikkelen en veranderen van de wijze waarop organisaties hun relaties extern en intern, met klanten, partners en medewerkers vormgeven. Relaties met klanten kan een bedrijf vormgeven door bijvoorbeeld te gaan verkopen via het internet, een activiteit die ook wel als 'e-Commerce' wordt aangeduid. Relaties met partners en/of leveranciers kan een bedrijf ondersteunen door extranets, waarmee selectief toegang kan worden verleend aan een beperkte groep partners. Relaties met medewerkers

Dr. J.A. Emanuels is partner bij KPMG Consulting N.V. met als specifieke aandachtsgebieden New Business Planning en eFinance. Prof. Dr. O.C. van Leeuwen is partner bij KPMG Consulting met als specifieke aandachtsgebieden Financieel Management in relatie tot de besturing van organisaties en de hiervoor benodigde informatie. Daarnaast is hij als hoogleraar Bestuurlijke Informatieverzorging/Administratieve Organisatie werkzaam aan de Vrije Universiteit te Amsterdam. kunnen worden onderhouden met behulp van intranets, netwerken die beveiligd zijn voor toegang van buitenaf, maar die eveneens gebaseerd zijn op webtechnologie. Onderstaande figuur geeft dit schematisch weer.

\section{Figuur 1}

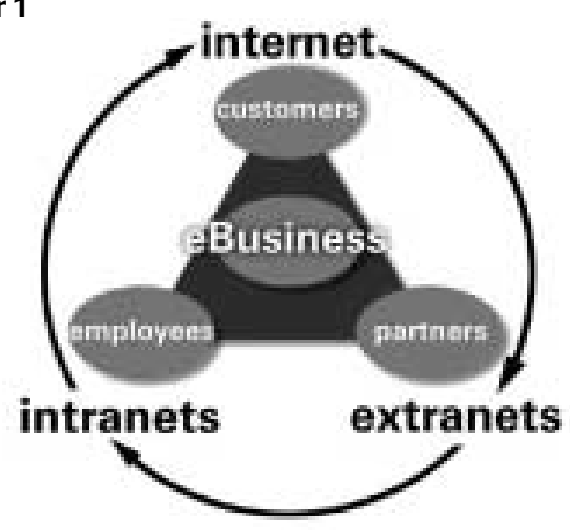

E-Business gaat dus verder dan uitsluitend het verkopen van goederen/diensten via het internet. Het is veeleer het toepassen van nieuwe communicatietechnologie in de gehele waardeketen waarin een organisatie opereert.

Het is waarschijnlijk dat de meeste organisaties geleidelijk de slag zullen maken van 'bricks' ('oude economie') naar het in substantiële zin gebruikmaken van de genoemde vormen van e-business ('clicks'). Uiteraard blijft de oude economie nog bestaan. Slechts enkele organisaties zullen geheel in eBusiness-ondernemingen worden getransformeerd en zullen de oude waarden van papieren, fabrieken, winkels en kantoren afschaffen.

De veranderingen in organisaties als gevolg van de implementatie van e-business hebben een effect op het rapportageproces zelf. In de meest vergaande vorm betekent dit dat de individuele beslisser altijd en overal over de actuele door hem gewenste perfor- 
mance-informatie kan beschikken. 'Shared Service Centers' (ook wel genoemd 'Accounting Houses') kunnen dit gegevensverwerkende proces faciliteren. Dit zijn zelfstandige organisatorische eenheden die voor de 'interne klanten' invoer en verwerking van basisinformatie verzorgen en zich in de informatieverstrekking over de resultaten van de verschillende processen (inkoop, verkoop, et cetera) richten op de specifieke behoefte van diezelfde klanten. Shared Service Centers bieden de mogelijkheid om besparingen te realiseren en tegelijkertijd de kwaliteit van de transactieverwerkende en rapportageprocessen te vergroten.

Anderzijds worden de belangrijkste processen die de financiële functie ondersteunt, beïnvloed door de invoering van e-Business (Van Leeuwen en Wemmenhove, 2001). Deze processen zijn met name:

- Het verkoopproces: veranderingen in de vormgeving van de communicatie met klanten door e-commerce leidt tot veranderingen in het gehele verkoop of order-to-cash-proces (kortweg $\mathrm{O} 2 \mathrm{C}$ ), inclusief alle administratieve processen die dit proces van input voorzien en/of de output uit dit proces verwerken (zoals: orderontvangst, afleveropdracht, facturering en debiteurenbewaking).

- Het inkoopproces: alle administratieve processen die verbonden zijn met het inkoopproces (purchase-topay of P2P) zullen worden beïnvloed door implementatie van on line-inkoopprocessen ('e-procurement'), omdat de communicatiepatronen met en rolverdeling tussen organisatie en leveranciers wijzigen. Bestellingen worden niet meer geregistreerd door de verkopende partij, maar kunnen op basis van een on line-catalogus rechtstreeks in de systemen van partners/leveranciers worden ingevoerd en zonder tussenkomst van mensenhanden gefactureerd (e-billing).

- Processen gerelateerd aan personeelsmanagement (HR): binnen de organisatie zelf verandert de wijze waarop met medewerkers wordt gecommuniceerd door de toenemende functionaliteit van intranets, maar ook door een vergaande ondersteuning van werknemers bij het managen van hun routinematige werkzaamheden (elektronische uren en projectadministratie, on line-kostendeclaraties, et cetera) en het faciliteren van zaken als e-learning (on line-opleiden) en het bewaken van de eigen prestatie-indicatoren.

Doel van dit artikel is het verder uitwerken van de effecten die de hierboven geschetste ontwikkelingen op de financiële functie hebben ${ }^{2}$ en stil te staan bij de vraag wat dit voor de controller betekent. In dit kader worden achtereenvolgens het $\mathrm{O} 2 \mathrm{C}$, het $\mathrm{P} 2 \mathrm{P}$, de administraties rondom het personeel, shared service centers en het rapportageproces behandeld. Vervolgens zullen we ingaan op de vraag welke rol de controller kan spelen in het veranderingproces dat met de invoering van e-Business gepaard gaat.

\section{Order to Cash (O2C)}

Het elektronische verkoopproces begint bij het aan een afnemer beschikbaar stellen van een productaanbod en eindigt bij het afleveren van de bestelde goederen dan wel bij het ontvangen van de betaling, als dit later geschiedt.

O2C kan zowel binnen een B2C-markt ('Business-toConsumer') als een B2B-markt ('Business-toBusiness') worden toegepast. O2C binnen een B2Cmarkt laat zich kenmerken door vaak relatief kleine transacties, waardoor volume (omzet) wordt behaald met behulp van grote aantallen transacties of een breed assortiment. Typerend voor dit type transacties is de particulier die eenmalig of met lage frequentie via het web bij een bedrijf een bestelling doet. De kans op wanbetaling in dit proces dient te worden geminimaliseerd door een kredietwaardigheidstoets of gegarandeerd betaalmiddel met controle vooraf. Een ander kenmerk is dat de klant overal ter wereld aflevering van het gekochte product kan wensen. Beperking van het afzetgebied, dan wel een aansluitend zeer sterk georganiseerd logistiek proces (supply chain) is noodzakelijk om aan de klantwensen te voldoen. Deze kenmerken maken het O2C-proces in een B2C-omgeving complex, duur en met risico's omgeven.

Voorbeelden van succesvolle implementaties kenmerken zich door:

- een professionele en consistente wijze van communicatie via het elektronische verkoopkanaal met de klant;

- door focus op de core business (zo mogelijk aansluitend bij de branding via andere kanalen);

- strategische samenwerking met (externe) partners. Bijvoorbeeld op het gebied van afdekken van kredietrisico's, logistiek en afwikkeling van de betaling.

Daarnaast zijn er initiatieven succesvol gebleken omdat de levering van diensten per definitie direct en elektronisch ('on line') plaatsvindt (zoekmachines) of omdat ze een enorme kostenbesparing kunnen opleveren ten opzichte van fysieke levering (denk aan de verkoop van on line-verzekeringspolissen).

Binnen de B2B-omgeving kan onderscheid worden gemaakt tussen het aanbod via internet van maat- 
werkproducten en standaardproducten. In geval van $\mathrm{O} 2 \mathrm{C}$-proces binnen een $\mathrm{B} 2 \mathrm{~B}$-markt kan er sprake zijn van specifiek aan de klanteisen aangepaste producten of halffabrikaten. Hierdoor kan een groot volume worden bereikt met een relatief beperkt assortiment. Er wordt vaak gewerkt voor een beperkt aantal bekende klanten, waardoor de kredietrisico's bekend of goed in te schatten zijn. Door deze kenmerken is het O2Cproces eenvoudiger, goedkoper en met minder risico's omgeven dan binnen de B2C-omgeving. Hierdoor kan $\mathrm{O} 2 \mathrm{C}$ eenvoudiger succesvol worden geïmplementeerd. Door de nauwe samenwerking met de klant kan ook eerder sprake zijn van 'supply chain-integratie': de leveranciers, magazijnen, transporteurs, et cetera worden als het ware direct aangestuurd op basis van de relatie met de uiteindelijke klant (verticale integratie). Vooral wanneer de aanbieder marktleider is voor het betreffende product, kunnen de voordelen van supply chain-integratie optimaal worden benut door strategische samenwerking tussen aanbieder en afnemer en kunnen grote efficiencyvoordelen worden gerealiseerd door 'single data entry', het eenmalig inbrengen van de benodigde gegevens voor het gehele proces (zoals omschrijving, aantal stuks, afleverdatum, locatie, et cetera).

Indien er binnen een B2B-aanbod sprake is van een standaard (groot) assortiment (bijvoorbeeld kantoorartikelen), kan dit gunstige perspectief op een snelle en risicoarme implementatie enigszins worden beïnvloed, omdat de klanten dan ook onbekende 'prijskopers' kunnen zijn (primair op zoek naar de laagste prijs). De risico's (bijvoorbeeld op wanbetaling) en derhalve ook de te treffen maatregelen, zijn dan vergelijkbaar aan die in de $\mathrm{B} 2 \mathrm{C}$-omgeving.

Het O2C-proces binnen zowel een B2B- als een B2Comgeving komen sterk overeen. De verschillende processtappen binnen $\mathrm{O} 2 \mathrm{C}$ worden hierna globaal beschreven:

\section{Orderontvangst}

- Binnen B2C zal er veelal sprake zijn van het beschikbaar stellen van een catalogus via het web. Binnen B2B kan er naast het beschikbaar zijn van een catalogus op het web, ook sprake zijn van een zogenaamde virtuele marktplaats (een webpagina), waar vraag en aanbod bij elkaar komen.

- De klant/afnemer krijgt on line informatie over het beschikbare productaanbod. Prijzen en beschikbaarheid zijn direct duidelijk, waardoor nee-verkoop (teleurstelling) niet meer voorkomt. Ook offertes kunnen on line worden aangevraagd en afgewikkeld. $\mathrm{Er}$ is sprake van een efficiënter en sneller proces (onder andere minder inzet van telefonische service- afdelingen, et cetera), wat ook de klanttevredenheid ten goede komt.

Aan het begin van het proces worden eenmalig de ordergegevens vastgelegd. Vaak zelfs door de afnemer/ klant. Een goede vastlegging zorgt ervoor dat in het verdere proces geen aanvullende (handmatige) invoer van gegevens meer nodig is ('single data entry'). In veel gevallen zijn het nog steeds de traditionele kanalen (telefoon, fax) waarlangs de order uiteindelijk binnenkomt. Door gebruik te maken van 'workflow management', kunnen de documenten, na zonodig te zijn gedigitaliseerd, in elektronische vorm door de processen heen worden geleid.

\section{Orderacceptatie}

- Met behulp van een on line-kredietcontrole ('e-credit') kan de kredietwaardigheid van de afnemer/klant worden getoetst. Een kredietwaardigheidtoets kan plaatsvinden met interne gegevens (ervaringsgegevens betaalgedrag, uitstaand saldo openstaande vorderingen) of externe gegevens ('e-credit').

- Een on line-controle op de voorraadbeschikbaarheid. Eventueel kan er ook een geautomatiseerde on linekoppeling zijn met de catalogus, waardoor informatie over beschikbaarheid van producten of levertermijnen direct in de catalogus kunnen worden vermeld. Bij niet-beschikbaarheid van producten kan geautomatiseerd een alternatief product worden aangeboden, om zo de verkoopkansen optimaal te benutten.

- Op basis van de uitkomsten van de vorige twee stappen kan er on-line orderacceptatie en -bevestiging plaatsvinden.

\section{Orderverwerking}

- De door het systeem geaccepteerde order wordt direct elektronisch doorgeleid naar het afleveringsproces waar de order wordt klaargemaakt en afgeleverd bij de klant. Dit bevordert de snelheid waarmee wordt uitgeleverd, en door de elektronische gegevensoverdracht is er minder kans op fouten.

- De geaccepteerde order kan deel uitmaken van een totale oplossing binnen een distributieketen ('supply chain'). In dat geval kunnen op basis van de order direct de voorraadniveau's worden gecontroleerd en kan er automatisch een inkooporder worden gegenereerd (ingang P2P-proces).

- Het systeem kan geautomatiseerde (sub)grootboekboekingen genereren en een elektronische factuur maken, die on line ('electronic bill presentement') aan de afnemer beschikbaar kan worden gesteld.

- Doordat het systeem continu de status van de order kent, is het mogelijk de klant on line te voorzien van 
'tracking \& tracing'-informatie. De klant weet continu wat de status van de order is.

\section{Orderafhandeling}

- Betaling kan plaatsvinden met inmiddels breed ingevoerde internet-betalingsopties ('e-payments') of via een meer traditionele betaalwijze.

- De ontvangst van de betaling kan worden verwerkt met behulp van een e-banking systeem. Hiermee wordt ook het (sub)grootboek direct bijgewerkt.

- Indien geen betaling binnenkomt, kan met behulp van e-creditsystemen automatisch debiteurenbeheer (e-credit) plaatsvinden. Het systeem kent on line de status van de betaling en de ondernomen acties, zoals verstuurde aanmaningen, of maant de debiteurenbeheerder aan tot het nemen van voorgeschreven acties. Indien de klant een rekening-courantsaldo heeft, wordt de hoogte en het risico automatisch bewaakt, in geval van vervolgorders.

\section{Figuur 2}

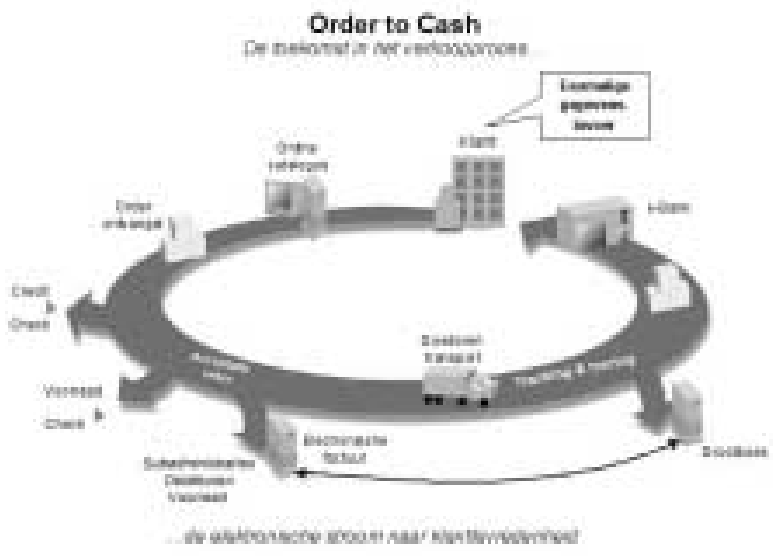

\section{Purchase to Pay (P2P)}

Het elektronisch inkoopproces begint bij het signaleren van een inkoopbehoefte en het plaatsen van een order bij een leverancier. Het eindigt bij het ontvangen van de goederen en het betalen van de leverancier.

O2C en P2P zijn qua proces in vele opzichten elkaars spiegelbeeld. Een belangrijk verschil is dat $\mathrm{P} 2 \mathrm{P}$ in vrijwel alle gevallen gepaard zal gaan met een relatie met een of meerdere business partners, die het efficiënt plaatsen en afwikkelen van elektronische inkooporders ('e-procurement') mogelijk maken. Met andere woorden, P2P zal vrijwel altijd plaatsvinden in een business-to-business-(B2B)omgeving. De voornaamste processtappen worden hierna beschreven:

\section{Offerte en prijsvergelijking}

Het internet biedt ruime mogelijkheden voor de inkoopfunctie om het aanbod op specificaties, prijs en levercondities te vergelijken. Vaak is dit echter een zeer tijdrovende zaak, waar alleen gespecialiseerde 'surfers' zonder hulp uitkomen. Er ontstaan dan ook steeds meer sites waar, al dan niet tegen kosten, een dergelijke dienstverlening wordt aangeboden. In een aantal gevallen hebben aanbieders zichzelf via een portal of marktplaats georganiseerd, teneinde een en ander zo transparant mogelijk te maken. Grotere organisaties, waar veel wordt ingekocht op basis van betrekkelijk standaard specificaties, geven hun vaste leveranciers soms toegang tot het intranet, zodat de inkopers nog sneller kunnen beschikken over de juiste informatie (afgesproken kortingen, aanbiedingen, et cetera).

\section{Bestellen en ontvangen}

De on line-bestelling kan direct in de financiële administratie van de besteller als verplichting worden verwerkt. Voordeel hiervan is dat bij ontvangstmelding automatische vergelijking kan plaatsvinden en de voorraad kan worden bijgewerkt. Ondertussen kan de besteller door middel van 'tracking \& tracing'-opties, die op steeds meer sites worden aangeboden, de logistieke voorrang van de afhandeling van zijn order bijhouden.

Figuur 3

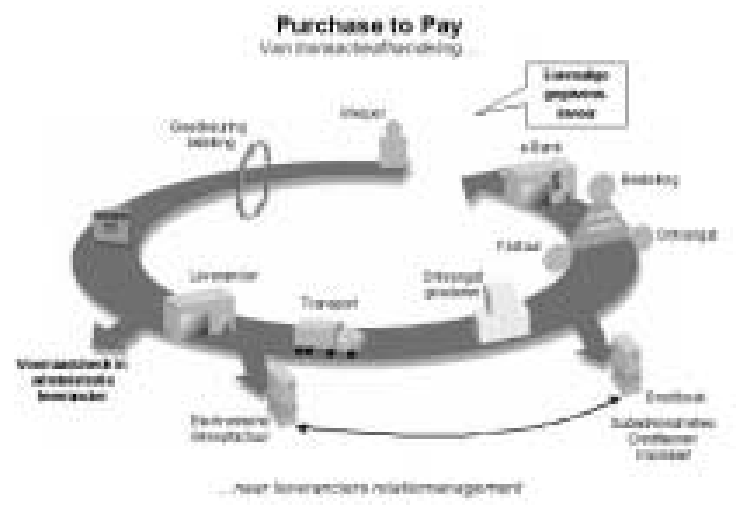

\section{Betalen}

Indien de factuur elektronisch ('electronic bill presentment') wordt aangemaakt, kan deze direct met de verplichtingenadministratie en ontvangstregistratie worden vergeleken en kan betaalbaarstelling, eventueel gekoppeld aan autorisatie en limieten, plaatsvinden. De bevoegdheid om on line-betalingen te verrichten in een 'open' systeem (niet gekoppeld aan een 
rekening-courantverhouding, maar direct via bank of creditcard), zal aan goede autorisatieprocedures moeten worden onderworpen.

\section{Het Hire-to-Retire-proces (H2R)}

De talrijke activiteiten die plaatsvinden rond het personeel - van werving tot en met pensionering - worden door de financiële functie ondersteund met activiteiten die wij aanduiden met de term 'Hire-to-Retire', ofwel het H2R-proces. De kern van het H2R-proces bestaat uit het bijhouden van personeelsgegevens. Naast persoons- en salaris-, fiscale en andere gegevens gaat het daarbij over vakantie, ziekte, auto, pc-privé, maar ook over de geïmplementeerde regels en procedures rond het personeelsbeleid, wervingsmanagement, trainingsmanagement, declaraties, 'staff appraisal', opvolging en in toenemende mate ook verplaatsingsmanagement, van carpooling tot vergoedingssystemen voor fietsen. De processen zijn vaak arbeidsintensief en foutgevoelig - het laatste vloeit voort uit het feit dat er zo veel variabele gegevens in het proces zitten.

Dit geheel aan processen zal in de meeste gevallen worden ondersteund door financieel administratieve totaaloplossing (ERP-pakket) of door een gespecialiseerd systeem, dat vaak al diverse mogelijkheden biedt voor selfservice van medewerkers. Rond deze IT-kern bevinden zich weer toepassingen voor verschillende deelgebieden. Ook kunnen allerlei relaties worden gelegd tussen het systeem en een al of niet extern werkend wervingsbureau of een uitzendbureau. Zulke partijen kunnen vroegtijdig informatie krijgen over diverse ontwikkelingen die actueel zijn onder medewerkers en in het personeelsbestand.

Ook hier zien we dat het systeem er 'aan de voorkant', in dit geval dus richting medewerker, heel verschillend uit kan zien. Steeds meer organisaties gaan ertoe over om medewerkers toegang tot dit systeem te geven via een webpagina. Deze webtoepassing kan de relatie tussen de organisatie en haar medewerkers vergaand stroomlijnen en verbeteren. Met webgebaseerde toepassingen kan een medewerker veel van de hem of haar betreffende zaken in het systeem zelf invullen of aangeven, een verschijnsel dat bekend staat als 'employee self service'.

Voor zowel management als medewerkers is één van de grote voordelen van een webgebaseerd H2R-proces dat het hierdoor mogelijk kan worden om veel 'korter op de bal te spelen'. Met andere woorden: allerlei onaange- name zaken, zoals onjuiste declaraties, kunnen veel vaker en in een veel vroeger stadium worden voorkomen. Voor personeel zijn procedures en voorwaarden transparanter, wat problemen achteraf kan voorkomen.

Een toepassing die veel ergernis en onduidelijkheid kan voorkomen, zijn de zogenaamde 'Travel \& Expenses'-modules. Zo kan een medewerker in Hotel Grand Luxe een suite boeken en de declaratie direct op een webpagina inboeken vanaf zijn hotelkamer. Het systeem kan dan direct een foutmelding geven als die medewerker niet geautoriseerd is voor een suite, en tevens melden dat Hotel Grand Luxe niet op de lijst van geautoriseerde hotels staat en een suggestie voor een alternatief doen. Ook zijn koppelingen mogelijk met dienstverleners die de financiële transactie afhandelen.

Uiteraard moet zo'n systeem het management de mogelijkheid bieden diverse regels in het systeem te implementeren, zoals rond eerder genoemd voorbeeld over welke medewerker is gemachtigd tot het doen van bepaalde uitgaven en welke uitzonderingen hierop bestaan, terwijl tevens de controle op deze uitgaven al (grotendeels) in het systeem zit ingebakken.

\section{- De organisatie van het gegevensverwerkende proces: Shared Services}

Uit de beschrijving die wij hebben gegeven van de $\mathrm{O} 2 \mathrm{C}-$, P2P- en $\mathrm{H} 2 \mathrm{R}-$ processen blijkt dat een belangrijk kenmerk van deze processen is dat de vastlegging van informatie op papier zal verschuiven naar elektronische vastleggingen. Prijslijsten, bestelorders, facturen, et cetera zijn daarbij elektronisch beschikbaar. Veelal zullen deze vastleggingen tevens de basisregistraties vormen voor de mutatie in de financiële en/of ERP-systemen. Als we ons tevens realiseren dat deze registraties niet meer door de financiële administratie hoeven te worden verricht, maar rechtstreeks gekoppeld zijn aan handelingen van de inkopers, verkopers, klanten en leveranciers, dan leidt dit tot een tweetal belangrijke conclusies:

- In de eerste plaats dat de financiële functionaris (controller) er alert op moet zijn dat de functiescheidingen en interne controles die in de 'papieren' omgeving aanwezig waren, op de een of andere manier worden vervangen door gelijkwaardige maatregelen (ingebouwde controles) in de e-business-omgeving.

- In de tweede plaats betekent het dat de reeds ingezette ontwikkeling naar een meer efficiënte, servicegerichte en geüniformeerde backoffice sterker zal toenemen. Immers, de snelheid en continuïteit waarmee transac- 
ties kunnen worden geïnitieerd door de toepassing van e-business, kan er toe leiden dat de backoffice de zwakste schakel wordt als daar niet voldoende aandacht aan wordt besteed. Deze elektronische stromen moeten vervolgens op uniforme wijze worden afgewikkeld. Wij verwachten dat het managen van deze informatiestromen (Workflow Management) een steeds belangrijkere rol zal gaan spelen.

Daarnaast zal het zo zijn dat in de O2C-, P2P- en H2R-processen vrijwel altijd een aantal stappen nog handmatig zullen zijn of vragen om een menselijke interventie (bijvoorbeeld de ontvangst/afgifte van inkoopfacturen, vrachtbrieven, uitvoeren van controles, et cetera). Een voorbeeld van dergelijke hybride oplossingen is de situatie waarbij verkooporders binnen kunnen komen per telefoon, fax, e-mail, internetsite en post. Om al deze orders tijdig in hetzelfde systeem te verwerken, dienen processen efficiënt ingericht te zijn en dient er een soepele overgang van papieren naar elektronische stromen plaats te vinden.

Wij gaan er dan ook vanuit dat in grote organisaties de tendens tot het vormen van Shared Service Centers (al of niet uitbesteed, zie Van Horn, 2000), die gericht zijn op het efficiënt en kwalitatief hoogwaardig afhandelen van deze gegevensverwerkende processen, zich zal doorzetten en dat organisaties die deze ontwikkeling nog niet hebben ingezet, daar de komende tijd over gaan nadenken (Van Leeuwen, 2000; Bos en Van Leeuwen, 1999). Het accent zal daarbij wel verschuiven van het vraagstuk van besparing van personeels- en locatiekosten (niet alles hoeft meer op één plek te gebeuren) naar het toevoegen van waarde door het centraal uitrollen en integreren van procedures en applicaties op het gebied van relatiebeheer ('customer relationship management'), inkoop ('eprocurement'), facturering ('electronic billing'), et cetera, en er voor te zorgen dat deze kunnen 'praten' met de gebruikte ERP-pakketten en de performance management-systemen ${ }^{3}$.

\section{Het rapportageproces (Data to Reporting: D2R)}

Bij de ontwikkeling die de rapportage doormaakt, en vooral de manier waarop het management van informatie wordt voorzien, gaat het met name om het vergroten van de toegevoegde waarde. Dat betekent hier vooral: het verstrekken van actuelere informatie en van informatie die het management helpt bij het realiseren van de strategie en het sturen van de organisatie, waarbij het onder meer gaat om prestatieindicatoren (Van Breemen e.a., 1997).
Deze ontwikkeling was natuurlijk al geruime tijd in gang gezet vóór de opkomst van het internet. Maar ook hier zien we internet de ontwikkeling versterken en versnellen. Bij het management ontstaat de behoefte om overal en op elk moment toegang te hebben tot liefst volledig up-to-date-informatie over bedrijf, organisatie en omgeving. Hij of zij wil bijvoorbeeld de omzet van de afgelopen dagen kunnen zien op het intranet, als het even kan straks ook via de mobiele telefoon. Dit soort toepassingen wordt mogelijk gemaakt door webtechnologie en door de capaciteit en dynamiek van de moderne 'datawarehouse'-systemen (applicatie onafhankelijke gegevensbanken). Echter, het introduceren van dergelijke oplossingen (Reportals, Virtual Close ${ }^{4}$, et cetera) vraagt ook om een enorme verandering in de wijze waarop het management de onderneming bestuurt, verantwoordelijkheden delegeert en verantwoording aflegt over de te nemen beslissingen ('governance'). Het creëert een vorm van transparantie en een 'aanspreek'-cultuur die meerdere kanten op kan werken (werknemers, managers, aandeelhouders). De controller is een belangrijk adviseur bij het realiseren van deze veranderingen. Zijn rol zal verschuiven van het produceren en inhoudelijk controleren van de rapportages (dit wordt een geautomatiseerd proces) naar het adviseren over de relevante prestatie-indicatoren en het effectief bijsturen van de business op basis hiervan.

Raakt de controller betrokken bij het versnellen van de rapportages en het inrichten van een 'reportal', of een op webtechnologie gebaseerd Executive Information System (EIS), dan kan dat in de praktijk neerkomen op het opnieuw leren ontwikkelen van een 'taal'. Eén voorbeeld. Het woord 'omzet' betekent voor de verkoper 'bruto-omzet' (liefst inclusief BTW). Terwijl het voor de controller 'bruto-omzet minus verkoopkosten' kan betekenen. In een grote organisatie met verspreid werkende business units kan het een majeure inspanning zijn om die zaken op één lijn te krijgen. Daar kan het bovendien zo zijn dat in afdeling A de gegevens tot gisteren zijn bijgewerkt, maar die van afdeling $B$ tot twee maanden geleden. Dat betekent dat het inrichten van de webpagina voor de rapportage in veel gevallen het gemakkelijkste deel is van een webgebaseerd D2R-proces. De bulk van het werk zit in het harmoniseren van de informatieverwerkende processen en het invoeren van een door de gehele organisatie gebruikt datamodel.

\section{Rol van de controller}

In het voorafgaande is aan de hand van een aantal deelprocessen een beeld geschetst van wat 'e' voor de 
financiële functie gaat betekenen. Wat betekent dit nu voor controllers en tot welke veranderingen moet dit in een specifiek geval leiden? Het beeld is verre van eenduidig, maar naar onze mening is er toch wel een aantal hoofdlijnen te geven.

Kort voor de harde landing die de Nasdaq maakte in het voorjaar van 2000 , deed de grap de ronde dat CFO's van internetbedrijven maar twee zorgen hadden, één: hoe ze zoveel mogelijk verlies konden maken, twee: hoe ze dat verlies door effectief 'relatiebeheer' konden afwentelen op hun aandeelhouders... De werkelijkheid leek hier soms akelig dicht in de buurt te komen. Een jaar later staat de wereld er heel anders voor. Zeiden investeerders die geld staken in einitiatieven een jaar geleden nog 'hier heb je een zak met geld en zie maar', daar vragen ze nu direct 'wanneer zie ik mijn geld terug?'

De rol die de controller hierin speelt, is eveneens sterk veranderd. Als finance op dit moment over een e-Initiatief zegt 'het kan niet', dan heb je als initiatiefnemer een probleem. Maar dat wil natuurlijk niet zeggen dat de controller ermee kan volstaan de ontwikkeling van e-Business binnen zijn of haar bedrijf tegen te houden. De CFO's van enkele op dit punt vooruitstrevende 'oude economie'-bedrijven zijn zelfs de stellige mening toegedaan dat finance deze verandering moet drijven. Finance zit immers in een unieke positie om te voorkomen dat e-Business het bedrijf 'overkomt'.

Het is uiteraard allereerst aan het lijnmanagement van de organisatie om de strategie te bepalen en op basis daarvan de prioriteiten vast te stellen. De controller die optreedt als businesspartner, zal echter niet uitsluitend afwachten wat deze prioriteiten worden. Wil het management offensief nieuwe markten ontwikkelen met behulp van webtechnologie, dan zal de rol van finance in het daaropvolgende verandertraject een adviserende zijn. Het vertalen van de strategische keuzes in businessmodellen en het vertalen van de kritische succesfactoren in meetbare indicatoren op basis waarvan de nieuwe business kan worden gepland en gemonitored, is een essentieel onderdeel van deze adviesrol. Ligt de eerste prioriteit in het verbeteren van de interne processen teneinde doelstellingen als efficiency, klantgerichtheid of snelheid van besluitvorming te verbeteren, dan zal finance in het veranderproces een meer leidende rol moeten spelen.

De belangrijkste redenen die wij daarvoor hebben aangegeven zijn de mate waarin de financieel admini- stratieve processen, en met name de basisregistraties, vervlochten raken met de businessprocessen (inkoop, verkoop, HRM). E-Business raakt dus alle financieel administratieve processen. In de meeste gevallen zit de complexiteit van e-Business juist niet zozeer in het inrichten van de website, maar in de processen in de organisatie (en dikwijls, steeds vaker zelfs, daarbuiten) die daarmee samenhangen.

De voorbeelden van waar het mis gaat met het financiële proces op het moment dat het bedrijf overstapt op e-Business, zijn legio. Van het koppelen van de verkeerde prijstabellen aan de webpagina tot het 'neeverkopen', omdat het voorraadsysteem niet goed aansluit met de catalogus op de site. Dit zijn allemaal zaken die vroeger ook al mis konden lopen - het verschil is alleen dat het een bedrijf nu veel meer kan opbreken. De directe schade of misgelopen omzet kan groot zijn.

Achter de schermen van e-Business is de koppeling met en het zicht op de primaire processen voor het goed inrichten van de financieel administratieve processen dus van cruciaal belang. De taak van financiële functie komt daarbij steeds meer te liggen op het beoordelen van die koppeling en van de controlemaatregelen die in de processen zitten ingebouwd. Met andere woorden: de controller moet nog beter dan voorheen begrijpen hoe die primaire processen zelf in elkaar zitten. Steeds minder tijd zal binnen ebedrijven worden besteed aan het uitvoeren van de controles zelf.

\section{Conclusie: 'Back to the future' (of finance)}

Zo op het eerste gezicht lijkt e-Business de controller voor een compleet nieuwe serie vragen te plaatsen. In de inleiding van dit artikel hebben we al gezegd dat dit volgens ons maar ten dele waar is. Nieuw is de centrale plaats die webtechnologie neemt in de veranderingen, waardoor er mogelijkheden ontstaan om nieuwe en geïntegreerde financieel administratieve processen op te zetten. Dit betekent dat de controller bij het inrichten van zijn administratieve processen een rol vervult tezamen met andere afdelingen binnen de organisatie in het $\mathrm{O} 2 \mathrm{C}$-, het $\mathrm{P} 2 \mathrm{P}$ - en het $\mathrm{H} 2 \mathrm{R}-$ proces. Verder moet hij uiteraard zijn eigen D2R-proces inrichten. In concernstructuren komt de vraag op of de administratie niet beter in de vorm van een shared service centrum dan gedistribueerd kan worden gevoerd.

Deze ontwikkeling kan óók worden gezien als een logische vervolgstap in een evolutieproces dat binnen de financiële functie al veel langer gaande is. De rol 
van de controller groeide bij veel organisaties in de afgelopen periode uit van 'scorekeeper' tot 'business partner'. Tegelijkertijd onderging de financiële functie als geheel een aantal kenmerkende veranderingen. De aandacht van de financiële functie zal door gebruik te maken van de nieuwe mogelijkheden nog meer verschuiven van het beheren van het gegevensverwerkende proces, naar het bewaken van de businessdoelstellingen.

Wel is er een belangrijk verschil met het voorafgaande tijdperk: internet maakt dat de keuze voor verandering binnen de financiële functie niet langer min of meer vrijblijvend is. Dat leek tot nu toe vaak wel het geval te zijn. In sommige bedrijven is de financiële functie, ondanks alle ontwikkelingen die de afgelopen jaren hebben plaatsgevonden, een soort eiland gebleven dat tamelijk los opereerde van de rest van de organisatie. In de tijd van e-Business is deze 'status aparte' voor geen enkele financiële functie nog vol te houden. Zelfs controllers die al gewend waren zich als businesspartner van het management op te stellen, zullen in het e-Tijdperk nog een stap verder moeten gaan. Zonder e-Finance (een financiële functie die de mogelijkheden van internettechnologie ten volle benut) geen e-Business, daar zullen steeds meer bedrijven spoedig achter komen. Het opereren van de CFO als 'manager van informatiestromen' is daarbij wat ons betreft de minimale variant (Haack, Kruyt en Ramaekers, 2000). In veel gevallen zullen kernprocessen worden getransformeerd. Het bestuurbaar maken en houden van de organisatie is in een dergelijk transformatieproces een randvoorwaarde. Dus zal veel afhangen van de poractieve opstelling van diezelfde CFO en zijn controllers. Vroeg of laat komt het management met de wens 'wij willen e-Business gaan doen. Op dat moment moeten zij kunnen aangeven 'we zijn er klaar voor' of uit kunnen leggen waarom dat niet het geval is.

Tegelijkertijd is het met al die nieuwe mogelijkheden van groot belang tussen de bomen het bos niet uit het oog te verliezen. Om richting te houden kunnen we één abstractieniveau hoger gaan zitten en de vraag stellen: waar draait het in 'finance' nu werkelijk om? Wat ons betreft zijn dat twee dingen, het bijhouden van de administratie en het uitvoeren van de controlfunctie, waarvan het verstrekken van managementinformatie een deel is. Voor beide kunnen we, op hetzelfde hoge abstractieniveau, veranderingsdoelstellingen formuleren. Voor de eerste (de administratie bijhouden) moet het doel vooral zijn: meer efficiency. Voor het tweede (het uitvoeren van de controlfunctie) moet het doel zijn: meer toegevoegde waarde leveren Deze twee doelstellingen zijn de centrale krachten geweest achter de evolutie van de financiële functie in de afgelopen jaren, en zullen die centrale rol blijven spelen in de verdere evolutie van de komende jaren. De webtechnologie die we in dit artikel kort hebben aangeduid, kán, mits op de juiste wijze ingezet en geïmplementeerd, bijdragen aan het realiseren van beide doelstellingen.

Deze twee (meer efficiency, meer toegevoegde waarde) zijn de drijvende krachten achter een evolutie die naar onze mening tamelijk universeel is voor de financiële functie van uiteenlopende organisaties. In veel bedrijven bereikt de financiële functie momenteel het stadium dat we 'finance of the future' noemen, waarin de diverse taakgebieden van de financiële afdeling dermate zijn gegroeid dat zij niet meer in één functionele eenheid passen (zie figuur 4$)^{5}$.

\section{Figuur 4: evolutionaire stadia van de financiële functie}

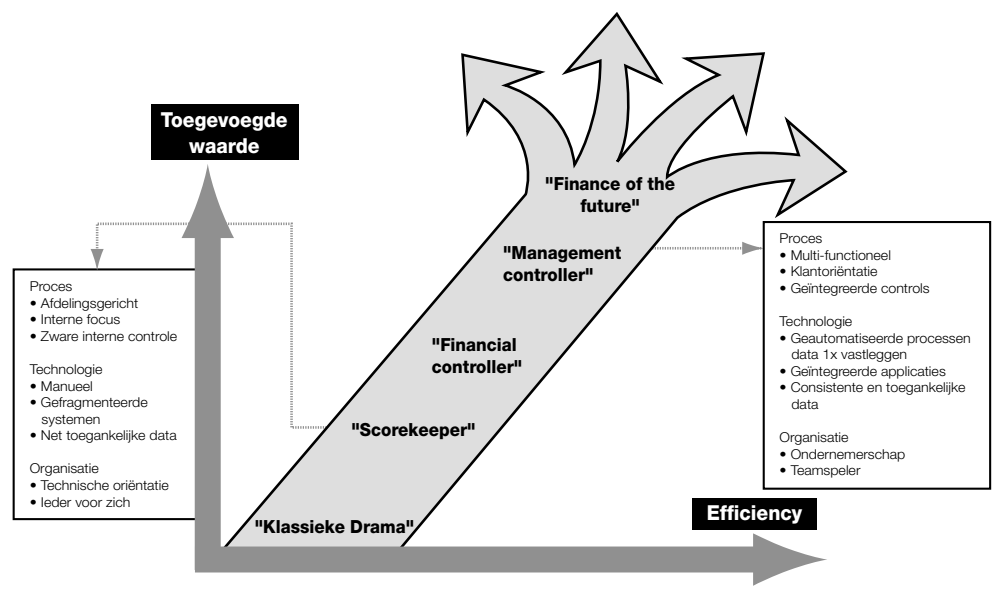

De vraag van controllers wat in hun situatie de meest logische en noodzakelijke stap is wat betreft de ontwikkeling van de financiële functie in hun specifieke geval, zal sterk afhangen van de vraag in welk stadium van het evolutieproces hun financiële functie zich op dit moment feitelijk bevindt. Om in te haken op de ontwikkeling van e-Business, zullen veel financiële afdelingen een flinke inhaalslag moeten maken.

Concluderend zou een controller bij het inrichten van zijn administratieve processen na moeten gaan op welke wijze hij tezamen met andere afdelingen binnen de organisatie het $\mathrm{O} 2 \mathrm{C}-$, het $\mathrm{P} 2 \mathrm{P}-$ en het $\mathrm{H} 2 \mathrm{R}$ proces kan uitwerken. Verder moet hij uiteraard zijn eigen D2R-proces inrichten. In concernstructuren 
komt daarnaast de vraag op of de administratie niet beter in de vorm van een shared service centre kan worden gevoerd. De controller kan hiermee bereiken dat de financiële functie veelal efficiënter wordt gevoerd en dat de afnemers van diensten van de financiële functie meer toegevoegde waarde ervaren.

\section{Literatuur:}

Bos, K. en O.C. van Leeuwen, (1999), 'Heeft u de financiële functie die u wilt?', in: Holland Management Review, issue 67, pp. 60-68.

Breemen, R. van, O.C. van Leeuwen en R.H.I. van Schoubroeck, (1997), Management en informatie: de kunst van het kiezen, Samsom, Alphen aan den Rijn.

Conijn, F., F. van Erck, en C. Taia Boneco, (2001), E-Finance. De toekomst van de financiële functie, in: Tijdschrift Controlling, maart.

Fahy, M.J. en M. Donovan, (1999), Shared Service Centres: The Irish experience, in: Accountancy Ireland, August, pp. 7-9.

Fisher, L., (1998), A problem shared, in: Accountancy International, August, pp. 40-41.

Haack, R.M.C.J., H.P. Kruyt en J.C.H.A.M. Ramaekers, (2000), Gevolgen van E-Business voor de financiële functie: De CFO als manager van informatiestromen, in: Tijdschrift Financieel Management, 20/6, november/december, pp. 10-20.

Horn, H.A.L.M. van, (2000), Voor en tegen de outsourcing van de financiële functie, in: Maandblad voor Accountancy en Bedriffseconomie, 74/5, mei, pp. 156-167.

Irvine, J., (1998), Onwards and outwards, in: Accountancy international, December, pp. 46-47.

Jarman, N., (1998), Shared Service Centres building for Europe, in: Management Accounting, June, pp. 32-33.

Kersnar, J., (1998), All for one and one for all, in: CFO Europe, July/August, pp. 12-18.

King, P., P. Leong en E. Durrant, (1998), The road to implementing Shared Service Centres, in: Management Accounting, September, pp. 32-33.

Leeuwen, O.C. van en P. Wemmenhove, (2001), Een verkennend onderzoek naar trends in Finance \& Control: 'De toekomst van de controller en de financiële functie; een zaak voor managers!', in: Maandblad voor Accountancy en Bedrijfseconomie, 75/5, mei, pp. 217-228.

Leeuwen, O.C. van, (2000), 'It's life Jim, but not as we know it.', in: Tijdschrift Controlling, 15/6, pp. 8-11.

Outram, R, (1999), You will be assimiliated, in: CA Magazine, July, pp. 1115.

Singleton-Green, B., (1996), Slipping of the core, in: Accountancy International, May, pp. 50-51.

\section{Noten}

1 De enquête werd gehouden onder ongeveer 200 bezoekers van het symposium 'e-Finance, de toekomst van de financiële functie', dat plaatsvond op 13 december 2000 in de RAl te Amsterdam. Zie ook: Conijn, F., F. van Erck en C. Taia Boneco: 'E-Finance, De toekomst van de financiële functie', in: Tijdschrift Controlling, maart 2001.

2 Ook in de literatuur over de financiële functie speelt de opkomst van het internet een voorname rol. Zo stijgt in de ABI database (omvat 1200 tijdschriften op het gebied van de financiële functie) het aandeel van artikelen rondom dit thema de laatste twee jaar van $20 \%$ naar $30 \%$.

3 Ook in de literatuur over de financiële functie blijkt de opkomst van het fenomeen shared services. Zo stijgt in de ABI database (omvat 1200 tijdschriften op het gebied van de financiële functie) het aandeel van artikelen rondom dit thema de laatste vier jaar gecombineerd met outsourcing van $14 \%$ naar $22,5 \%$.

4 'Reportals' zijn internet- of intranetsites waarop actuele gebruikers specifieke managementinformatie wordt weergegeven. Het begrip 'Virtual Close' verwijst naar de mogelijkheid om financiële boekingen direct te verwerken in een on line-managementinformatiesysteem, waardoor het moment van de periodeafsluiting niet meer relevant is.

5 Overigens kan het hele ontwikkeltraject nog beginnen met een soort voorstadium dat wij het 'klassieke drama' noemen, dat als onderscheidend kenmerk heeft dat zelfs een goedkeurende accountantsverklaring ontbreekt - dan kun je natuurlijk helemaal niets beginnen, en zul je eerst puin moeten ruimen en de kosten voor lief nemen. Zie Bos, K. en Van Leeuwen, O.C., 'Heeft u de financiële functie die u wilt?', Holland Management review, 1999. 